5-HT contents of the brain. The possibility exists that some other indole products of the tumour or unidentified intermediary metabolites of $5-\mathrm{HT}$, having structural similarity, may behave in the same way and are capable of producing mental change. Whatever mechanism may be involved for the cerebral metabolism of serotonin, in the light of the above experimental evidences, and in the absence of any other known cause, the neurological and mental symptoms presented by this patient, along with attacks of flushing, strongly suggests that a disturbance of cerebral metabolism of serotonin was responsible for the symptoms.

I am most grateful to Mr. Stephen Power, Con- $\subseteq$ sultant Surgeon, for his generous guidance and helpful $\Rightarrow$ criticisms, and Dr. Shackle for the post-mortem examination and histology slides, Mr. Nicholson and Dr. Shackle for the photographs, and Miss Johns for her secretarial help.

\title{
REFERENCES
}

Amix, A. H., Crawford, T. A. B., and Gaddum, J. H. (1954): The Distribution of Substance P and 5-Hydroxytryptamine in the Central Nervous System of Dog, F. Physiol. (Lond.), r26, 596.

Biörck, G., Axen, O., and Thorson, A. (1952): Unusual Cyanosis in a Bor with Congenital Pulmonary Stenosis and Tricuspid Valve Insufficiency, Fatal Outcome, Amer. Heart $\mathcal{F}$., 44, 143.

Brodie, B. B., and Shore, P. A. (1957): A Concept for a Role of Serotonin and Norepinephrine as Chemical Mediator in the Brain, Ann. N.Y. Acad. Sci., 66, $63 \mathrm{I}$.

Cope, Z. (1 930): Metastases of Argentaffin Carcinoma in Testicle, Brit. F. Urol., 2, 268.

Feldberg, W., and Sherwood, S. L. (1954): Injections of Drugs into the Lateral Ventricle of Cat, F. Phy'siol. (Lond.), 123,148 .

Gaddum, J. H. (1953): Antagonism between Lysergic Acid Diethylamide and 5-hydroxytryptamine, F. Physiol. (Lond.), - I2I, I 5.

MalloRy, T. B. (I940): Case Records of the Massachusetts General Hospital, New Engl. F. Med., $222,686$.

Marrazzi, A. S., and Harts, E. R. (1955): Relationship of Hallucinogens to Adrenergic Cerebral Neurohumors, Science, 121, 365 .

Page, I. H., and Twarog, B. M. (1953): Serotonin Content of Some Mammalian Tissues, Urine and Method for its Determination, Amer. F. Physiol., 175, 157.

Schneider, J. A., and Yonkman, F. F. (1953): Action of Serotonin on Vagal Afferent Impulses in Cat, Amer. $\mathcal{F}$. Physiol., 174, 127.

Thorson, A., Biörck, A., Bjorkman, G., and Waldenstrom, J. (r954): Malignant Carcinoid of the Small Intestine with Metastases to the Liver, Valvular Disease of the Right Side of the Heart, Peripheral Vasomotor Symptomso Bronchoconstriction and an Unusual Type of Cyanosis: A Clinical and Pathological Syndrome, Amer. Heart $\mathscr{F}$ 47, 795 .

Undenfriend, S., Weissbach, H., and Bogdanski, D. F. (1957): The Distribution of Serotonin, 5-Hydroxytryptophan̄ Decarboxylase and Monoamine Oxidase in the Brain, $\mathcal{F}$. Neurochem., $\mathbf{1}, 272$.

Woolley, D. W., and Shaw, E. (r954): Some Neurophysiological Aspects of Serotonin, Brit. med. F., ii, r22.

\section{CHRONIC OSTEOMYELITIS OF THE UI،NA OCCURRING IN SYRINGOMYELIA}

\author{
R. S. Phillips, F.R.C.S. \\ The Royal Infirmary, Edinburgh 3
}

Although, in this day and age, acute and chronic osteomyelitis are seen much less than formerly, the conditions are by no means rare. However, chronic osteomyelitis of the ulna in the absence of a compound fracture is uncommon.

Trueta and Morgan (1954) reporting a series of cases of acute osteomyelitis, found the ulna to be the site of infection in four of one hundred patients. Blanche (1952) in his series, found two in 50 patients. Green, Nyhan and Fousek (1956) found the ulna involved in nine, in their series of 99 patients.
However, in these authors' series, the lesion was acute and occurred in infancy or childhood.

Acute and chronic pyogenic osteomyelitis, in adults, are even less common conditions. Reviewing the literature of the past 35 years, a direct reference to the conditions could be found on three occasions only. Variava (1935) described the acute condition in a patient with a compound fracture of both forearm bones. The radius, however, was involved maximally. Dufour (1933) demonstrated the radiological history of one patient with chronic 
ulnar infection. A further chronic case was reported by Hendriock (I939) who regarded the ulna as a rare site for localization of bone infection.

\section{Case History}

Mr. R. A., aged 49 , was admitted to hospital on September 24, 1960. His history was that in June, 1960, while pulling a heavy weight at work he experienced a sudden jerking sensation in the left forearm. Within a few hours his forearm had begun to swell, although it was seven days before this swelling was maximal. At the time of the accident he had noticed two septic abrasions on the left forearm. At this point he reported to his own practitioner for he had become generally unwell. His forearm was painful, swollen, red and stiff. Cellulitis was diagnosed and oral penicillin prescribed with resolution of signs and symptoms.

On September 14, 1960, the patient noticed a painless lump on the posterior aspect of the left forearm, associated with stiffness in the fingers. There was no systemic upset.

His previous history was significant in that in 1955 he had reported to another hospital with a rupture of the right biceps brachii. At that time there was noticed to be a dissociated loss of sensation in the right forearm and hand with obvious muscle wasting. A diagnosis of syringomyelia was made.

On examination, the patient was a stocky little man of healthy appearance. The conjunctivæ were well injected. There was no lymphadenopathy. On the posterior surface of the left ulna, at the junction of its proximal and middle thirds, there was a diffuse, nontender, bony swelling showing none of the characteristics of acute inflammation. Temperature $97^{\circ} \mathrm{F}$., pulse $60 / \mathrm{min}$., W.B.C. $6,500 / \mathrm{cu}$. mm., E.S.R. $6 \mathrm{~mm}$. $/ \mathrm{hr}$.

Examination of the locomotor and peripheral nervous systems revealed the following:

Upper Limbs. Right: Extreme wasting of thenar, hypothenar and interossei groups of muscles. There was no voluntary movement in these muscles. The wrist flexors showed normal power but only the flexors to the ulnar three fingers were functioning. Extension of the wrist was normal. Elbow and shoulder movements were normal. Left: The thenar, hypothenar and interossei groups of muscles were wasted but opposition of thumb and little finger was still possible. The third dorsal and palmar interossei had weak function. Wrist, elbow and shoulder movements were normal.

Lower Limbs. Normal motor power and sensation were noted. Reflexes were brisk and equal. Plantar reflexes were flexor on both sides. There was, in addition, a well-marked Horner's syndrome on the right side.

$\mathrm{X}$-ray films of the left forearm, taken on admission, showed patchy decalcification with periostitis and the presence of a sequestrum in the shaft of the ulna.

A diagnosis of chronic, active osteomyelitis of the shaft of the ulna was made, and the presence of syringomelia was confirmed.

\begin{tabular}{|c|c|c|c|}
\hline & & Right & Left \\
\hline $\begin{array}{l}\text { Reflexes: } \\
\text { Tricens }\end{array}$ & & & \\
\hline Triceps $\quad \ldots$ & . & - & 一 \\
\hline $\begin{array}{ll}\text { Biceps } & \ldots \\
\text { Supinator } & . .\end{array}$ & . & 二 & 二 \\
\hline Pain and temperatur & & Greatly & Diminished \\
\hline Light touch . & $\ldots$ & Present & Present \\
\hline Postural sensibility & $\ldots$ & Normal & Normal \\
\hline Vibration & $\ldots$ & Absent & Present \\
\hline
\end{tabular}

Treatment and Progress

On September 29, 1960, under a general anæsthetic the ulna was approached by a longitudinal incision overthe bone. The lesion was exposed and thoroughly? saucerized. The bone fragments and sequestrum, with $\overrightarrow{-}$ some thick creamy pus, were sent to the bacteriologist. $\vec{\rho}$ After operation, the limb was immobilized in an above $\frac{\pi}{8}$ elbow plaster. Crystalline penicillin, 0.5 mega units b.d. was given intramuscularly for seven days.

Bacteriology: a profuse growth of coagulase-positiv Staphylococcus aureus highly sensitive to penicillin. $\infty$

The patient was discharged home on January 5,1960 and three weeks later the plaster was removed becausee of the patient's inability to use the opposite limbi Radiographs taken at intervals showed progressive regeneration of the ulna. Those on December 7, 19600 showed an almost complete return to normal contour? The wound healed rapidly, although a sero-sanguinous $\overrightarrow{-}$ bacteriologically sterile discharge was apparent for few days.

\section{Discussion}

There seems to be little likelihood that patient's ulnar lesion was due to hæmatogengis spread from a distant focus of infection, but ratee to be consequent upon an acute cellulitis in the forearm. It is unlikely that spread of infection to bone occurred directly, in the absence of absces? formation in association with cellulitis. A superficiab cellulitis may destroy, in fibrosis, the lymphatics coursing proximally as a subcutaneous plexus with the result that inflammatory products and viable organisms are carried into a deeper plane and by retrograde flow into bone.

It may be suggested that the coincident syrin윽 gomyelia may have predisposed to the superficiat. skin infection and the resultant osteomyelitis That this may be so in the hand and fingers is undoubted, but in this patient's case the left uppeg limb was less involved than the right, and the forearm itself had normal sensation. Indeed there is no reference in the literature of the past to years to osteomyelitis of the ulna occurring as a complica을 tion of, or in association with, syringomyelia.

I am grateful to Mr. J. H. S. Scott for his permission to publish the details of this case.

\section{REFERENCES}

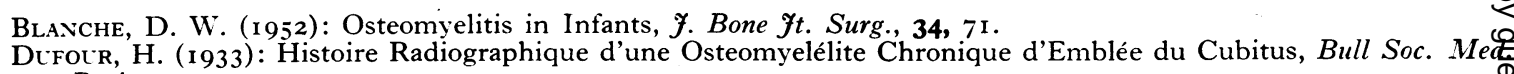

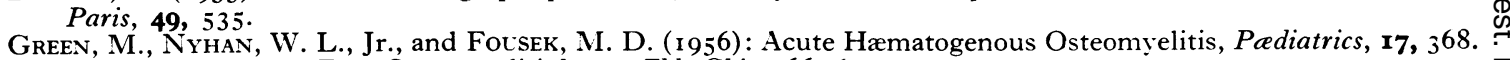

HeNDRIOCK, A. (I939): Zur. Osteomyelitisfrage, Zbl. Chir., 66, 675.

Trieta, J. and Morgan, J. D. (1954): Late Results in the Treatment of 100 Cases of Acute Hæmatogenous Osteo

myelitis, Brit. F. Surg., 41, 449.
Variava, D. H. (I935): Un cas d'Osteomyélite Traité par la Methode du Solarium, Ann. Inst. Actinol., 9, 20. 